being modiated by sense organs located in the mantlo musoulature. This indicates that sensory pathways of several modalities located in the mantlo region converge on units in the supra-cesophageal ganglion.

These results support the theory of chemoroception as a function of the osphradium at least in Buccinum undatum. Failure to record activity in response to light tactile stimulation suggests that the osphradial mochanorecoptors, if any, are insufficiently sensitive to act as sediment dotectors as suggested by Hulbert and Yonge. During the course of the experiments it has boen noted that copious production of mucus occurs from the hypobranchial gland, osphradium and mantle surface. This must severely impode the entry of particlos into the mantle cavity in the natural situation and their contact with any part of the mantle surface.

\section{F. BAIrEY}

M. S. Laverack

Gatty Marine Laboratory,

University of St. Andrews.

${ }^{2}$ Copeland, M. J., J. Kxp. Zool., 25, 177 (1918).

'Wolper, C., Z. vergl. Physiol., 32, 272 (1950).

3 Brown, A. C., and Noble, R. G., Nature, 188, 1045 (1960)

${ }^{4}$ Hulbert, G. C. F. B., and Yonge, C. M., Nature, 139, 840 (1937).

${ }^{5}$ Yonge, C. M., Phil. Trans. Roy. Soc., B, 232, 443 (1947).

${ }^{6}$ Kohn, A. J., Amer. Zool., 1, 291 (1961).

'Fretter, V., and Graham, A., British Prosobranch Molluses (Ray Society, London, 1962).

\section{Suppression of Gemma-cups in Marchantia by High. Humidity}

IT was noticod that gomma-cups in the Now Zealand liverwort Marchantia berteroana $\mathrm{L}$. and $\mathrm{L} .(=M$. tabularis Noes) were not produced when the pots wore covered with glass or polythene shoets. That this effect is the result of incroased humidity has boon confirmed by growing plants in the saturated atmosphere of a permanent-spray house, but protected from diroct falling water. All experiments were carriod out on sets of 60 plants, started from disks of Marchantia thallus $1 \mathrm{~cm}$ in diamoter, grown in pots of sterilized gardon soil. In all experiments except the second every disk had its counterparts, cut from the same thallus, in the corresponding position in each treatment so that the material under the different treatments was exactly comparable.

In one represontative experimont no gemma-cups at all were producod on $a_{\text {unit of }} 60$ plants during ninetoon woeks' growth in a saturated atmosphere, whereas the control plants in normal air out of doors had, in the same timo, produced a total of 234 gemma-cups (moan $3 \cdot 9 \pm 0.98$ /plant). This difference is highly significant $(P<0.001)$

$\Lambda$ second oxporiment, using twice as many plants, resulted in a total of 10 gemma-cups (mean $0.08 \pm 0.75$ / plant) in saturated air comparod with 1,049 cups (mean $8 \cdot 74 \pm 1 \cdot 18 /$ plant) in normal air. The difference is again highly significant $(P<0.001)$.

A similar effect was shown by a third experiment in which units covered with sheot polythene or uncovered wore grown in cabinets at three different temporatures, averaging approximately $5^{\circ}, 10^{\circ}$, and $15^{\circ} \mathrm{C}$. The uncovered plants produced $2\left(5^{\circ} \mathrm{C}\right), 9\left(10^{\circ} \mathrm{C}\right)$ and $175\left(15^{\circ} \mathrm{C}\right)$ gernmacups totalling 186 , whilo the covored plants produced no gemma-cups even at $15^{\circ} \mathrm{C}$. The total production of gemma-cups was low, probably as a result of the comparatively high ambient relative humidity (about 75 per cent) in the cabinots.

Table 1 prosents the results of a fourth experiment, where batches of 6 plants were transferrod into the spray

Table 1. EFPECT OF INCREASING EXPOSURE TO DRY CONDITIONS ON NUMBKR OF GRMML-COPS FORMED. COUNTS MADE AFTER 106 DAYS. SIX PLANTS IN FACH TRFATMENT
IN Fin

$\begin{array}{lllllllllll}\text { Days in dry conditions } & 1 & 2 & 4 & 8 & 16 & 24 & 32 & 40 & 48 & 56\end{array}$ $\begin{array}{lllllllllll}\text { Total No. of gemma-cups } & 1 & 6 & 0 & 1 & 11 & 61 & 36 & 58 & 56 & 78\end{array}$ house after increasing periods in dry air out of doors. The equation for the regression of number of gomma-cups formed on days of dry conditions is $y=30 \cdot 8+1 \cdot 40(x-$ $23 \cdot 7)$, which is highly significant $(P<0.001)$.

After the end of these experiments the plants produced gametangiophores and it was possible to determine their sex, revealing that, in the material used, male plants are able to produce far more gemma-cups than are fernale plants. For the second experiment, the pooled comparative mean numbors of gemma-cups per plant aro $60 \cdot 13 \pm 7 \cdot 52$ for male and $4 \cdot 29 \pm 4 \cdot 48$ for fomale plants. This difference is not due moroly to tho male plants being larger, since the average number of gemma-cups per unit of area of the thallus is male $0.87 / \mathrm{cm}^{2}$ compared with female $0.07 / \mathrm{cm}^{2}$. The sex difforence also accounts for the rather low num. bors of gemma-cups on the plants of the first experiment, for all these turned out to be fomalo.

The procise humidity which is responsible for this suppression of gemma-cup formation is not yot known.

Department of Botany,

George A. M. ScotT

Univorsity of Otago,

Dunedin, Now Zealand.

\section{The Genus Oceanopapaver}

Tнт monotypic genus Oceanopapaver was established for the naming of $O$. neocaledonicum by Guillaumin ${ }^{1}$. Because of cortain characters which need not be discussed here he relegated his new genus to Papaveracea. Friedel ${ }^{2}$ cast some doubt on this classification and suggested that the plant showed a number of characters not unlike those of the Cistacene. Fedde ${ }^{s}$, in a reviow of the Papaveraceat, expressed scepticism about allocating this new genus to that family. Among other criteria he saw somo difficulty in finding a papaveraceous plant endemic to the tropical New Caledonia in the southern hemisphere.

Thanks to Prof. H. S. McKee, Commonwealth Scientific and Industrial Rescarch Organization, Canberra, Australia I was able to make an examination of this plant for alkaloids. $400 \mathrm{~g}$ of dried material were available, collected when only a few of the seeds had matured. Fortunately this is the stage in most herbaceous plants when the alkaloid content is at a maximum.

The coarsely ground material was thoroughly extracted with methanol, the methanol was evaporated from the extract, the latter extracted with slightly acidified water, the aqueous extract filtered, and exhausted with repeated fresh portions of ether. (The ethor extract failed to yield fumaric acid--a common constituent of papaveraceous plants.) A test portion of the aqueous extract did not give a precipitate with potassium mercuric iodide-a test which when positive is an almost certain indication of alkaloids. So far no alkaloid-boaring plants are known which give a negative test with this reagent.

Nevertheless, the aqueous solution was rendored basic with ammonia and extracted with several successive portions of chloroform. The residue from the latter was stirred with aqueous oxalic acid, the filtered solution exhausted with ether, made alkaline again, and extracted with chloroform. 'The residue from the latter dissolved only partly in dilute acid and the solution did not give a precipitate with the aforementioned reagent.

Inasmuch as all plants of the Papaveraceae, which have so far been examined, have yielded alkaloids, their complete absence in $O$. neocaledonicum can be regarded as sufficient cause for relegating this plant to another family.

Dominion Rubber Co., Ltd.,

R. H. MANSKE

Research Laboratories,

Guelph, Ontario, Canada.

1 Guillaumin, A., Bull. Soc. bot. France, r9, 225 (1932).

${ }^{2}$ Friedel, F., Bull. Soc. bot. France, 80, 33 (1933).

${ }^{3}$ Fedde, F., in Fngler-Prantl, Die Naturlichen Pfanzenfamilien, 17 b. 